\title{
STRUKTUR MODAL DAN PROFITABILITAS: STUDI EMPIRIS PADA PERUSAHAAN SEKTOR PERTAMBANGAN PERIODE 2014-2018
}

\author{
Devi Wahyu Utami ${ }^{1}$, Heni Hirawati ${ }^{2}$, dan Axel Giovanni ${ }^{3}$ \\ 1,2,3 Universitas Tidar, deviwahyutami@gmail.com, heni.hirawati@untidar.ac.id \\ axelgiovanni@untidar.ac.id
}

\begin{abstract}
ABSTRAK
Penelitian ini bertujuan untuk membuktikan secara empiris pengaruh struktur modal terhadap profitabilitas perusahaan sektor pertambangan yang terdaftar di Bursa Efek Indonesia pada periode 2014-2018. Sampel penelitian terdiri dari 11 perusahaan pertambangan yang memenuhi kriteria penarikan sampel. Variabel independen adalah struktur modal, sedangkan variabel dependen adalah profitabilitas. Penelitian ini menggunakan data sekunder. Teknik pengumpulan data dilakukan dengan teknik dokumentasi, selanjutnya di analisis dengan menggunakan persamaan regresi linier berganda yang diolah melalui program software SPSS. Hasil dari penelitian memberikan bukti bahwa debt to equity ratio memiliki hubungan negatif signifikan terhadap profitabilitas. Sementara debt to asset ratio serta long-term debt to equity ratio tidak memiliki peran dalam menjelaskan profitabilitas.
\end{abstract}

Kata Kunci: struktur modal, debt to asset ratio, debt to equity ratio, long-term debt to equity ratio, profitabilitas

\begin{abstract}
This study aims to prove empirically the effect of capital structure on the profitability of mining sector companies listed on the Indonesia Stock Exchange in the 2014-2018 period. The research sample consisted of 11 mining companies that met the sampling criteria. The independent variable is the capital structure, while the dependent variable is profitability. This study uses secondary data. The data collection technique is done by using documentation technique, then it is analyzed using multiple linear regression equation which is processed through the SPSS software program. The results of this study provide evidence that the debt to equity ratio has a significant negative relationship to profitability. Meanwhile, the debt to asset ratio and longterm debt to equity ratio have no role in explaining profitability.
\end{abstract}

Keywords: capital structure, debt to asset ratio, debt to equity ratio, longterm debt to equity ratio profitability

Naskah diterima : 02-02-2021 Naskah dipublikasikan: 31-03-2021

\section{PENDAHULUAN}

Perubahan kondisi ekonomi secara makro dapat berdampak terhadap kondisi keuangan perusahaan. Perubahan kondisi ekonomi tersebut salah satunya diakibatkan oleh isu perang dagang yang terjadi antara Amerika Serikat dengan China. Kedua negara negara saling membuat kebijakan-kebijakan besar yang berdampak bagi perekonomian global, termasuk di Indonesia. Salah satu dampak yang ditimbulkan dari adanya perang dagang yaitu adanya probabilitas yang merugikan bagi industri batu bara yang mengalami penurunan harga yang signifikan sepanjang bulan Januari hingga Oktober 2019. Dilansir dari market.binis.com, 
(2019), pada Januari 2019, harga batu bara acuan tercatat sebesar US\$ 92,41 per ton turun menjadi US\$ 64,8 per metrik ton pada Oktober 2019.

Penurunan harga batu bara berdampak terhadap kinerja keuangan pada emiten sektor pertambangan. Kondisi ini dapat direpresentasikan melalui PT Bumi Resources Tbk pada kuartal III 2019 mencatatkan penurunan pendapatan sebesar 8,85 persen menjadi US\$ 751,85 juta dibandingkan dengan pendapatan kuartal III tahun 2018 sebesar US\$ 824,85 juta. Penurunan ini berdampak signifikan terhadap perolehan laba bersih perusahaan. Pada kuartal III 2019, laba yang dapat diatribusikan kepada pemilik entitas induk sebesar US\$ 76 juta atau turun sebesar 63 persen dibandingkan periode yang sama pada tahun 2018 sebesar US\$ 205,2 juta (Kontan.co.id, 2019). Dengan demikian, terbukti bahwa adanya perang dagang berdampak terhadap kinerja keuangan, salah satunya direpresentasikan melalui profitabilitas perusahaan.

Perusahaan harus mampu mempertahankan kinerja keuangan perusahaan dalam kondisi perekonomian saat ini. Kinerja keuangan dapat dianalisis dari profitabilitas perusahaan. Profitabilitas menjadi indikator kinerja manajemen dalam menangani asset perusahaan yang direpresentasikan melalui pendapatan dari aktivitas penjualan dan aktivitas investasi yang dilakukan oleh perusahaan terkait (Sudarmadji \& Sularto, 2007). Konsep profitabilitas menurut Novyanny \& Turagan (2013) yang menyatakan bahwa profitabilitas perusahaan menunjukkan prospek serta potensi perusahaan di masa yang akan datang apakah berada dalam kondisi yang baik atau tidak. Menurut Soewignyo (2020), profitabilitas menunjukkan kemampuan dalam menghasilkan profit atau laba dari penggunaan aset perusahaan. Semakin besar tingkat profitabilitas mengindikasikan bahwa semakin besar tingkat efisiensi perusahaan dalam menggunakan operasionalnya serta menjamin keberlangsungan hidup suatu perusahaan (Firmansyah, 2016). Faktor yang diduga memiliki peran atau pengaruh terhadap kinerja perusahaan yaitu keputusan struktur modal.

Struktur modal merupakan keputusan keuangan yang vital karena profitabilitas perusahaan secara langsung dipengaruhi oleh struktur modal (Nimalathasan, 2010). Keputusan struktur modal mengharuskan manajer memilih komposisi sumber dana yang tepat serta dapat memberikan kontribusi terhadap nilai perusahaan yang maksimal, sehingga struktur modal menjadi keputusan penting bagi pemegang saham perusahaan. Penentuan komposisi struktur modal dengan tepat diharapkan dapat meningkatkan keuntungan atau profitabilitas serta nilai perusahaan (Safitri et al., 2014). Dalam memenuhi kebutuhan modalnya, perusahaan dapat mencukupi kebutuhan modal baik bersumber dari pendanaan internal atau bersumber dari pendanaan eksternal (Rosita \& Gantino, 2017). Sumber pendanaan internal misalnya laba ditahan, sementara sumber pendanaan eksternal salah satunya yaitu hutang (Handayani \& Puspitasari, 2018). Perusahaan yang menggunakan hutang sebagai sumber pendanaaan harus berhati-hati karena hutang memiliki risiko akan timbulnya biaya bunga. Biaya bunga inilah yang akan mempengaruhi profitabilitas perusahaan. Semakin tinggi tingkat risiko yang dihadapi perusahaan berdampak terhadap semakin tingginya tingkat profitabilitas yang diharapkan menjadi imbal balik terhadap tingginya tingkat risiko yang dihadapi (Rosita \& Gantino, 2017).

Urgensi struktur modal sebagai aspek penting dalam keputusan keuangan perusahaan belum diimbangi dengan bukti studi empiris yang konsisiten. Pendapat tersebut dapat dibuktikan melalui hasil studi empiris Agmas Wassie (2020) dan Zulvia (2019) yang menyatakan bahwa 
struktur modal memiliki hubungan yang signifkan terhadap profitabilitas. Pendapat lain dinyatakan oleh Maulita \& Tania (2018) dan Arista \& Topowijono (2017) yang mengungkapkan struktur modal tidak memiliki pengaruh terhadap profitabilitas. Berdasarkan penelitian tersebut, masih menunjukkan hasil yang tidak konsisten sehingga penelitian mengenai pengaruh struktur modal terhadap profitabilitas masih diperlukan.

Penelitian ini dilakukan pada perusahaan sektor pertambangan go public pada periode 2014-2018. Pertambangan merupakan tahapan baik sebagian atau seluruh kegiatan yang meliputi kegiatan penelitian, kegiatan pengelolaan serta pengusahaan mineral maupun batubara seperti penyelidikan umum, tahap eksplorasi, tahap studi kelayakan, proses konstruksi, proses penambangan, proses pengolahan dan pemurnian, proses pengangkutan dan penjualan, serta kegiatan pascatambang. Perusahaan sektor pertambangan merupakan salah satu sektor terdampak adanya isu perang dagang China dengan Amerika Serikat (kontan.co.id), selain itu berdasarkan laporan keuangan yang dipublikasikan perusahaan sektor pertambangan mencatatkan kinerja perusahaan yang kurang baik pada sebagian besar perusahaan sektor pertambangan. Penelitian ini dilakukan untuk memberikan bukti secara empiris mengenai pengaruh struktur modal untuk menjelaskan variabilitas profitabilitas pada perusahaan sektor pertambangan periode 2014-2018.

\section{KAJIAN LITERATUR Profitabilitas}

Profitabilitas didefinisikan sebagai kemampuan perusahan dalam menciptakan atau menghasilkan keuntungan dengan menggunakan seluruh sumber daya yang dimiliki perusahaan. Sumber daya tersebut dapat berupa aktivitas penjualan, total aset, dan modal sendiri (Putri \& Puryandani, 2021). Profitabilitas perusahaan memberikan gambaran mengenai tingkat pengembalian keuntungan yang dapat diperoleh investor atas investasinya (Tauke et al., 2017). Profitabilitas mencerminkan bagaimana kinerja manajemen dalam menjaga efektivitas kegiatan operasi perusahaan. Ross et al. (2017) mengungkapkan bahwa profitabilitas menjadi indikator untuk mengetahui tingkat efisiensi pengelolaan asset perusahaan. Selain itu, tingkat profitabilitas yang tinggi akan memperkecil kemungkinan perusahaan mengalami kesulitas keuangan (Putri \& Puryandani, 2021). Kapabilitas perusahaan dalam menciptakan laba dipengaruhi oleh beberapa aspek, salah satunya yakni struktur modal perusahaan.

\section{Struktur Modal}

Struktur modal merepresentasikan tingkat penggunaan utang dalam jangka panjang serta penggunaan ekuitas yang tercantum pada laporan neraca (Baker \& Martin, 2011). SaifAlyousfi et al. (2020) dan Vo (2017) mengungkapkan bahwa struktur modal merupakan keputusan fundamental terkait dengan proporsi hutang dan ekuitas jangka panjang secara optimal yang dapat mempengaruhi aktivitas bisnis perusahaan. Dao \& Ta (2020) mendefinisikan struktur modal sebagai campuran utang dan ekuitas yang digunakan perusahaan untuk membiayai asset produktif, kegiatan operasional dan pertumbuhan perusahaan di masa yang akan dating. Struktur modal sering disebut sebagai financial leverage. Menurut Ross et al. (2017) Leverage keuangan menunjukkan sejauh mana ketergantungan perusahaan terhadap penggunaan utang. Penggunaan leverage yang semakin tinggi menunjukkan semakin tingginya penggunaan utang untuk membiayai kegiatan investasi perusahaan

\section{Trade-off Theory}

Teori ini memberikan penjelasan mengenai besaran tingkat utang yang harus digunakan perusahaan untuk memaksimalkan manfaat penghematan pajak dengan mempertimbangkan biaya yang timbul sebagai akibat dari penggunaan utang (Detthamrong et al., 2017; Orlova et al., 2020). Perusahaan memperoleh manfaat penghematan pajak melalui biaya bunga yang 
timbul dari penggunaan utang (Giovanni et al., 2020). Biaya bunga inilah yang mampu menjadi faktor pengurang beban pajak yang ditanggung perusahaan. Baker \& Martin (2011) mengungkapkan bahwa perusahaan yang memiliki biaya pajak tinggi cenderung menggunakan utang yang lebih tinggi dibandingkan dengan perusahaan yang memiliki biaya pajak rendah. Meskipun utang dapat memberikan manfaat penghematan pajak, namun tidak mungkin perusahaan menggunakan utang untuk membiayai seluruh investasi. Hal ini disebabkan karena proporsi penggunaan utang yang tinggi akan memperbesar risiko perusahaan mengalami kesulitan keuangan (Karugu et al., 2018).

\section{Pecking Order Theory}

Paradigma pecking order theory memberikan penjelasan bahwa perusahaan memiliki tingkatan atau hirarki dalam menentukan keputusan sumber pendanaan yang didasarkan pada masalah informasi asimetris (Myer, 1984; Myers \& Majluf, 1984; Giovanni et al., 2020). Jajaran manajemen cenderung memiliki informasi yang lengkap mengenai nilai perusahaan dibandingkan dengan pihak eksternal seperti investor maupun kreditor. Dengan demikian, informasi asimetris antara kedua belah pihak mendorong manajer untuk mengimplementasikan hierarkis pembiayaan dimana lebih mengutamakan pembiayaan internal kemudian diikuti penggunaan utang dan penerbitan surat berharga berada pada urutan terakhir (Hang et al. 2018; Haron 2018). Hal tersebut dikarenakan penggunaan sumber dana utang memiliki risiko yang lebih rendah dibandingkan dengan penerbitan surat berharga (Zhang \& Liu, 2017).

\section{Struktur Modal dan Profitabilitas}

Menurut Ramli et al. (2019) penggunaan proporsi leverage dengan proporsi yang besar dari proporsi ekuitas dapat meningkatkan kinerja keuangan perusahaan. Jaisinghani \& Kanjilal (2017) menjelaskan bahwa penggunaan proporsi hutang yang optimal dapat membantu meminimalisir biaya modal keseluruhan dan meningkatkan profitabilitas. Di tinjau dari sudut pandang pecking order theory, penggunaan utang pada sumber pendanaan akan mengindikasikan bahwa perusahaan memiliki kekurangan dana internal guna membiayai kegiatan investasi perusahaan. Proporsi penggunaan utang yang tinggi akan memperbesar risiko keuangan perusahaan (Karugu et al., 2018). Penggunaan utang yang terlalu tinggi mengakibatkan kewajiban yang dibayarkan perusahaan semakin besar sehinga profitabilitas perusahaan semakin menurun. Sehingga semakin besar tingkat penggunaan utang perusahaan akan menurunkan profitabilitas perusahaan. Sehingga hipotesis alternatif yang diajukan dalam penelitian ini adalah:

H1: Struktur modal memiliki hubungan negatif dan signifikan terhadap profitabilitas.

\section{METODE PENELITIAN}

Penelitian ini termasuk dalam penelitian kuantitatif. Penelitian kuantitatif merupakan penelitian yang menggunakan data berupa angka-angka, analisis serta penarikan keputusan secara statistik. Populasi penelitian yaitu seluruh perusahaan pada sektor pertambangan yang listing di Bursa Efek Indonesia selama periode 2014-2018. Sampe penelitian diambil menggunakan nonrandom sampling dengan teknik penarikan sampel menggunakan purposive sampling. Metode ini dipilih dengan tujuan untuk memperoleh sampel penelitian yang sesuai dengan kriteria-kriteria yang ditetapkan oleh peneliti. Kriteria tersebut antara lain a) perusahaan sektor pertambangan yang listing pada Bursa Efek Indonesia periode 2014-2018 secara berturutturut. b) perusahaan menyampaikan laporan keuangan yang telah diaudit secara berturut-turut pada 2014-2018. c) perusahaan memiliki data laporan keuangan yang lengkap pada periode 2014-2018. e) perusahaan memiliki nilai debt to equity ratio, debt to asset ratio, debt to capital ratio, dan long term debt to equity lengkap periode 2014-2018. f) perusahaan memiliki nilai profitabilitas yang positif selama tahun 2014-2018 secara berturut-turut. Berdasarkan kriteria yang telah ditentukan, diperoleh 11 perusahaan yang telah memenuhi kriteria penarikan sampel penelitian 
Variabel dependen yaitu profitabilitas perusahaan. Menurut Rosita \& Gantino (2017), profitabilitas dapat diproksikan menggunakan return on asset (ROA). ROA menunjukkan rasio yang membandingkan nilai laba bersih perusahaan dengan total asset perusahaan.

$$
\text { ROA }=\frac{\text { Laba Bersih }}{\text { Total Asset }}
$$

Variabel independen yang digunakan yaitu struktur modal. Dalam penelitian ini, struktur modal diproksikan melalui debt to equity ratio, debt to asset ratio serta long term debt to equity ratio. Debt to equity ratio menunjukkan perbandingan antara total liabilititas terhadap total ekuitas perusahaan.

$$
\mathrm{DER}=\frac{\text { utang }}{\text { ekuitas }}
$$

Debt to asset ratio didefinisikan sebagai nilai yang membandingkan total liabilitas terhadap total asset perusahaan.

$$
\text { DAR }=\frac{\text { utang }}{\text { asset }}
$$

Long term debt to equity ratio didefinisikan sebagai perbandingan antara total liabilititas jangka panjang dengan total ekuitas perusahaan.

$$
\text { LDER }=\frac{\text { Total liabilitas jangka panjang }}{\text { Total Ekuitas }}
$$

Skema hubungan antar variabel dalam penelitian ini dapat digambarkan sebagai berikut:

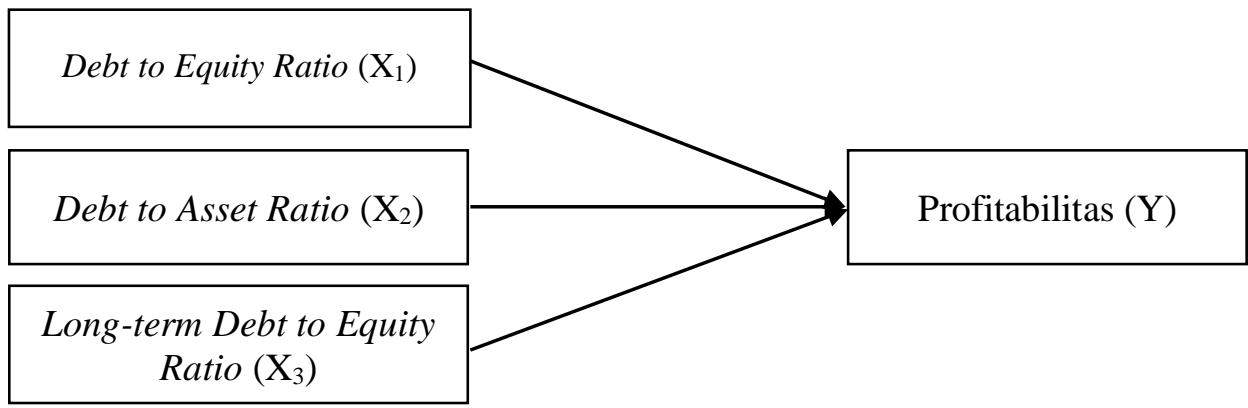

Gambar 1. Kerangka Penelitian

Data penelitian yang digunakan merupakan data sekunder yang mengacu pada informasi yang telah disediakan melalui sumber data. Data penelitian diperoleh melalui tinjauan laporan keuangan perusahaan yang telah diaudit yang diakses melalui website resmi perusahaan dan Bursa Efek Indonesia. Prosedur pengumpulan data diperoleh dengan studi dokumen dengan menggunakan dokumen sekunder. Studi dokumen sekunder dilakukan dengan menganalisis literatur yang relevan dan sesuai dengan topik penelitian.

Metode statistika yang digunakan adalah statistika inferensial melalui teknik analisis regresi linier berganda dimana tingkat signifikansi diasumsikan sebesar lima persen $(\alpha=5 \%)$. Pengolahan data dilakukan dengan menggunakan software pengolah data SPSS versi 25. Penarikan hasil penelitian didasarkan pada a) pengaruh yang signifikan ditunjukkan oleh nilai signifikansi $(\alpha)<0,05$. b) tidak terdapat pengaruh yang signifikan ditunjukkan oleh nilai signifikansi $(\alpha)>0,05$. c) variabel independen mempunyai pengaruh positif ditunjukkan melalui nilai koefisien pada variabel independen bernilai positif. d) variabel independen mempunyai pengaruh negatif ditunjukkan melalui nilai koefisien pada variabel independen bernilai negatif. 


\section{HASIL DAN PEMBAHASAN}

Hasil

Penelitian ini menggunakan mekanisme robust standard error untuk mengatasi masalah heteroskedastisitas dan autokorelasi yang terdapat dalam model regresi. Robust standard error adalah mekanisme yang valid dengan tujuan untuk mengatasi masalah autokorelasi serta heteroskedastisitas tanpa menghilangkan adanya autokorelasi serta heteroskedastisitas yang terdapat dalam model regresi (Gujarati and Porter, 2009). Robust standard error dilakukan untuk mengoreksi kesalahan standar model regresi agar pengambilan kesimpulan statistik tetap dapat dilakukan. Hasil estimasi model regresi dapat disajikan pada tabel berikut:

Tabel 1. Estimasi Final Model Regresi

\begin{tabular}{|c|c|c|c|c|c|}
\hline \multirow{2}{*}{ Variabel } & Prediktor & $\begin{array}{c}\text { Koefisien } \\
\text { Regresi }\end{array}$ & $\begin{array}{c}\text { Standard } \\
\text { Error }\end{array}$ & $\mathrm{T}_{\text {hitung }}$ & $P>|t|$ \\
\hline \multirow{3}{*}{ Struktur Modal } & DER & -0.5364 & 0.2229 & -2.4058 & 0.0198 \\
\cline { 2 - 6 } & DAR & 0.0813 & 0.0648 & 1.2534 & 0.2158 \\
\cline { 2 - 6 } & LDER & -0.5148 & 0.5039 & -1.0215 & 0.3118 \\
\hline \multicolumn{2}{|c|}{ Konstanta } & 1509.8330 & 324.0192 & 4.6597 & 0.000 \\
\hline \multicolumn{2}{|c|}{ Prob > F } & \multicolumn{3}{c|}{0.0070} \\
\hline \multicolumn{2}{|c|}{$\mathrm{R}^{2}$} & \multicolumn{5}{c}{0.3180} \\
\hline
\end{tabular}

Sumber: Data sekunder diolah (2020)

\section{Koefisien Determinasi}

Berdasarkan hasil pengolahan data pada tabel 1, diperoleh koefisien determinasi ditunjukkan dengan nilai sebesar 0,3180 atau sebesar 31,80 persen. Sehingga disimpulkan bahwa sebesar 31,80\% variabel profitabilitas dapat dijelaskan oleh variabel struktur modal yang diproksikan melalui debt to equity ratio (DER), debt to asset ratio (DAR) serta longterm debt to equity ratio (LDER). Sementara sebesar 68,20\% variabilitas profitabilitas dipengaruhi oleh variabel diluar model regresi.

\section{Uji Statistik F}

Berdasarkan hasil uji statistik F dapat disimpulkan bahwa variabel struktur modal yang direpresentasikan melalui debt to equity ratio, debt to asset ratio serta longterm debt to equity ratio secara bersama-sama atau simultan memiliki pengaruh terhadap profitabilitas perusahaan. Hal ini dibuktikan dengan nilai Prob > F (0.0070) lebih kecil dari asumsi tingkat signifikansi $(\alpha$ $=5 \%$ ). Berdasarkan hasil uji statistik $\mathrm{F}$, dapat dibuktikan bahwa model regresi telah terspesifikasi dengan tepat.

\section{Uji Statistik t}

Berdasarkan hasil uji statistik t, memberikan bukti bahwa variabel struktur modal dengan diproksikan melalui debt to equity ratio memiliki pengaruh yang signifikan terhadap profitabilitas. Sementara struktur modal yang diproksikan oleh debt to asset ratio (DAR) dan long-term debt to equity ratio (LDER) tidak terbukti memiliki pengaruh terhadap struktur modal. Hasil uji statistit $t$ model regresi pada penelitian ini dapar dirangkum melalui tabel berikut: 
Tabel 2. Hasil Uji Statistik t Model Regresi

\begin{tabular}{|c|l|l|l|l|}
\hline Variabel & \multicolumn{1}{|c|}{ Prediktor } & \multicolumn{1}{|c|}{ Nilai t thitung } & \multicolumn{1}{c|}{$\boldsymbol{P}>|\boldsymbol{t}|$} & \multicolumn{1}{c|}{ Keterangan } \\
\hline \multirow{3}{*}{ Struktur Modal } & DER & -2.4058 & 0.0198 & Signifikan \\
\cline { 2 - 5 } & DAR & 1.2534 & 0.2158 & Tidak Signifikan \\
\cline { 2 - 5 } & LDER & -1.0215 & 0.3118 & Tidak Signifikan \\
\hline
\end{tabular}

Sumber: Data sekunder diolah (2020)

Hasil estimasi Uji Statistik t pada penelitian ini dapat dijabarkan sebagai berikut:

a. Hasil uji statistik t pada tabel 2 menunjukkan bahwa nilai $\mathrm{P}\rangle|\mathrm{t}|$ yang diperoleh variabel debt to equity ratio (DER) adalah 0.0198 dan nilai t hitung sebesar -2.4058. Nilai t hitung sebesar -2.4058 menunjukkan bahwa arah koefsien dari variabel debt to equity ratio (DER) adalah negatif. Nilai $\mathrm{P}>|\mathrm{t}|$ uji statistik t sebesar $0.0198<$ asumsi tingkat signifikansi $(\alpha=5 \%)$ menunjukkan bahwa debt to equity ratio (DER) memiliki pengaruh signifikan terhadap profitabilitas.

b. Hasil uji statistik t pada tabel 2 menunjukkan bahwa nilai $\mathrm{P}>|\mathrm{t}|$ yang diperoleh variabel debt to asset ratio (DAR) adalah 0.2158 dan nilai t hitung sebesar 1.2534. Nilai t hitung sebesar 1.2534 menunjukkan bahwa arah koefsien dari variabel debt to asset ratio (DAR) adalah positif. Nilai $\mathrm{P}>|\mathrm{t}|$ uji statistik $\mathrm{t}$ sebesar $0.2158>$ asumsi tingkat signifikansi $(\alpha=5 \%)$ menunjukkan bahwa debt to asset ratio (DAR) tidak memiliki pengaruh terhadap profitabilitas.

c. Hasil uji statistik t pada tabel 2 menunjukkan bahwa nilai $\mathrm{P}>|\mathrm{t}|$ yang diperoleh variabel longterm debt to equity ratio (LDER) adalah 0.3118 dan nilai t hitung sebesar -1.0215. Nilai t hitung sebesar -1.0215 menunjukkan bahwa arah koefsien dari variabel longterm debt to equity ratio (LDER) adalah negatif. Nilai $\mathrm{P}>|\mathrm{t}|$ uji statistik t sebesar $0.3118>$ asumsi tingkat signifikansi $(\alpha=5 \%)$ menunjukkan bahwa long term debt to equity ratio (LDER) tidak memiliki pengaruh terhadap profitabilitas.

\section{Pembahasan \\ Pengaruh Struktur Modal (Debt to Equity Ratio) terhadap Profitabilitas}

Berdasarkan hasil pengolahan data pada tabel 1 , nilai signifikansi debt to equity ratio ditunjukkan dengan nilai sebesar $0.0198<0.05$. nilai tersebut menunjukkan bahwa bahwa secara parsial terdapat hubungan yang signifikan antara debt to equity ratio terhadap profitabilitas. Sementara koefisien debt to equity ratio sebesar -0.5364 , koefisien bernilai negatif menunjukkan adanya pergerakan yang berbanding terbalik antara debt to equity ratio dengan profitabilitas, artinya setiap terdapat peningkatan debt to equity ratio sebesar 1\% maka akan berdampak terhadap penurunan profitabilitas sebesar 0.5364 kali. Oleh karena itu dengan meningkatnya debt to equity ratio mengakibatkan penurunan profitabilitas perusahaan. Hasil penelitian ini sesuai dengan penelitian Zulvia (2019) yang menyatakan bahwa terdapat hubungan yang signifikan antara debt to equity ratio dengan profitabilitas. Arah pengaruh negatif menunjukkan bahwa asumsi pada pecking order theory dapat terbukti. Semakin tinggi tingkat penggunaan utang, akan memperbesar risiko keuangan perusahaan. Tingkat engunaan utang yang semakin besar akan menimbulkan kewajiban dan biaya bunga yang semakin besar pula sehingga dapat menurunkan profitabilitas perusahaan.

\section{Pengaruh Struktur Modal (Debt to Asset Ratio) terhadap Profitabilitas}

Berdasarkan hasil olah data pada tabel 1 , menunjukkan bahwa nilai signifikansi debt to asset ratio sebesar $0.2158>0.05$. nilai tersebut menunjukkan bahwa secara parsial debt to asset ratio tidak memiliki pengaruh terhadap profitabilitas perusahaan. Sementara koefisen debt to asset ratio sebesar 0.0813 , koefisien positif menunjukkan bahwa terdapat pergerakan yang berbanding lurus antara debt to asset ratio dan profitabilitas, artinya adanya peningkatan debt to asset ratio sebesar $1 \%$ akan meningkatkan profitabilitas perusahaan sebesar 0.0813 kali. Hasil penelitian yang menyatakan adanya hubungan yang tidak signifikan antara debt to asset ratio 
terhadap profitabilitas tidak sesuai dengan hasil penelitian Sukasa, Lolita; Suhadak; Hidayat (2017) yang mengungkapkan bahwa terdapat hubungan yang signifkan antara debt to asset ratio dengan profitabilitas. Pengaruh positif debt to asset ratio dengan profitabilitas mendukung trade-off theory dimana tingkat penggunaan utang yang semakin besar akan meningkatkan manfaat penghematan pajak yang diterima perusahaan sehingga profitabilitas perusahaan semakin meningkat.

\section{Pengaruh Struktur Modal (Long-term Debt to Equity Ratio) terhadap Profitabilitas}

Berdasarkan hasil estimasi final model regresi pada tabel 1, menunjukkan bahwa nilai signifikansi long-term debt to equity ratio sebesar $0.3118>0.05$, sehingga dapat ditarik kesimpulan bahwa secara parsial longterm debt to equity ratio tidak memiliki pengaruh signifikan terhadap profitabilitas. Sementara koefisen longterm debt to equity ratio sebesar 0.5148 , koefisien negatif menunjukkan adanya pergerakan yang berbanding terbalik antara longterm debt to equity ratio dengan profitabilitas, artinya setiap adanya peningkatan longterm debt to equity ratio sebesar $1 \%$ akan mengakibatkan penurunan profitabilitas perusahaan sebesar 0.5148 kali. Sekamin tinggi nilai longterm to equity ratio akan mengakibatkan semakin rendahnya profitabilitas perusahaan. Temuan penelitian memberikan bukti bahwa longterm debt to equity ratio tidak memiliki hubungan yang signifikan dengan profitabilitas. Hasil penelitian ini tidak sesuai dengan temuan Arista \& Topowijono (2017) yang menyatakan bahwa longterm debt to equity ratio memiliki pengaruh yang signifikan terhadap profitabilitas.

\section{PENUTUP}

\section{Simpulan}

Hasil penelitian ini memberikan bukti secara empiris mengenai peran debt to equity ratio terhadap profitabilitas, dibuktikan dengan estimasi hubungan negatif dan signifikan antara variabel debt to equity ratio terhadap profitabilitas. Penelitian ini juga memberikan bukti bahwa debt to asset ratio serta long term debt to equity ratio tidak memiliki peran dalam menjelaskan variabilitas profitabilitas.

\section{Saran}

Penelitian ini hanya mempertimbangkan aspek struktur modal dalam menjelaskan variabilitas profitabilitas. Untuk penelitian selanjutnya diharapkan dapat mempertimbangkan kondisi makroekonomi dan aspek kognitif dalam menjelaskan variabilitas profitabilitas perusahaan. 


\section{REFERENSI}

Arista, B., \& Topowijono, T. (2017). Pengaruh Struktur Modal Terhadap Profitabilitas (Studi Pada Perusahaan Sub Sektor Otomotif dan Komponen yang Terdaftar di Bursa Efek Indonesia Periode 2013-2015). Jurnal Administrasi Bisnis S1 Universitas Brawijaya, 46(1), 20-26.

Baker, H. K., \& Martin, G. S. (2011). Capital Structure and Corporate Financing Decisions: Theory, Evidence, and Practice. In Capital Structure and Corporate Financing Decisions: Theory, Evidence, and Practice. https://doi.org/10.1002/9781118266250

Dao, B. T. T., \& Ta, T. D. N. (2020). A Meta-Analysis: Capital Structure and Firm Performance. Journal of Economics and Development, 22(1), 111-129. https://doi.org/10.1108/jed-12-2019-0072

Detthamrong, U., Chancharat, N., \& Vithessonthi, C. (2017). Research in International Business and Finance Corporate Governance, Capital Structure and Firm Performance : Evidence from Thailand. Research in International Business and Finance, 42, 689-709. https://doi.org/10.1016/j.ribaf.2017.07.011

Firmansyah. (2016). Analisis Hutang, Aktiva , Likuiditas yang Mempengaruhi Return on Asset pada Sektor Hotel Restoran dan Pariwisata di Bursa Efek Indonesia. Jurnal Manajemen Dan Keuangan, 5(1), 489-495.

Giovanni, A., Utami, D. W., \& Widiyaningrum, E. (2020). Size, Growth, Profitability and Capital Structure. Jurnal REKOMEN, 4(1), 81-90.

Giovanni, A., Utami, D. W., \& Yuzevin, T. (2020). Leverage dan Profitabilitas dalam Memprediksi Financial Distress Perusahaan Pertambangan Periode 2016-2018. Journal of Business and Banking, 10(1), 151-167. https://journal.perbanas.ac.id/index.php/jbb/article/view/2292

Gujarati, D. N., \& Porter, D. C. (2009). Basic Econometrics (5th ed.). McGraw-Hill/Irwin.

Handayani, I., \& Puspitasari, R. (2018). Analisis Penggunaan Hutang Terhadap Profitabilitas Pada PT . Bakrieland Development Tbk dan PT . Summarecon Agung Tbk. Researchgate, May 2012, 1-10.

Hang, M., Geyer-Klingeberg, J., Rathgeber, A. W., \& Stöckl, S. (2018). Measurement matters-A meta-study of the determinants of corporate capital structure. Quarterly Review of Economics and Finance, 68, 211-225. https://doi.org/10.1016/j.qref.2017.11.011

Haron, R. (2018). Do Indonesian firms practice target capital structure? A dynamic approach. Journal of Asia Business Studies, 10(3). https://doi.org/10.1016/j.qref.2018.07.001

Jaisinghani, D., \& Kanjilal, K. (2017). Non-linear dynamics of size, capital structure and profitability: Empirical evidence from Indian manufacturing sector. Asia Pacific Management Review, 22(3), 159-165. https://doi.org/10.1016/j.apmrv.2016.12.003

Karugu, C., Achoki, G., \& Kiriri, P. (2018). Capital Adequacy Ratios as Predictors of Financial Distress in Kenyan Commercial Banks. Journal of Financial Risk Management, 07(03), 278-289. https://doi.org/10.4236/jfrm.2018.73018

Kontan.co.id. (2019). Laba anjlok 63\%, ini penjelasan managemen Bumi Resources (BUMI). https://investasi.kontan.co.id/news/laba-anjlok-63-ini-penjelasan-managemen-bumiresources-bumi

Market.binis.com. (2019). Harga Batu Bara Sulit Kembali Berjaya. https://market.bisnis.com/read/20191208/94/1178959/harga-batu-bara-sulit-kembaliberjaya

Maulita, D., \& Tania, I. (2018). Pengaruh Debt to Equity Rato (DER), Debt To Asset Ratio (DAR), Dan Long Term Debt To Equity Ratio (LDER) Terhadap Profitabilitas (Studi Pada Perusahaan Manufaktur Sub Sektor Makanan dan Minuman Yang Terdaftar di BEI Periode 2011-2016. Jurnal Akuntansi, 5(2), 132-137. p-ISSN 2339-2436. https://blog.hubspot.com/sales/debt-equity-ratio 
Myer, S. C. (1984). The Capital Structure Puzzle. The Journal of Finance, 39(3), 575-592.

Myers, S. C., \& Majluf, N. S. (1984). Corporate Financing and Investment Decisions When Firms Have Information The Investors Do Not Have. Journal of Finance Economics, 13(2), 187-221. https://doi.org/10.1016/S0040-4039(00)91429-1

Nimalathasan, B. (2010). Capital Structure And It's Impact On Profitability: A Studi Of Listed Manufacturing Companies In Sri Lanka. Global Journal of Management and Business Research, 10 (2 (ver. 1.0)), 7-16.

Novyanny, M. C., \& Turagan, J. A. (2013). Pengaruh Likuiditas, Ukuran Perusahaan, Umur Perusahaan dan Pertumbuhan Perusahaan Terhadap Profitabilitas Pada Perusahaan Jasa Sektor Perdagangan, Jasa \& Investasi Yang Terdaftar Pada Bursa Efek Indonesia. Jurnal Manajerial Dan Kewirausahaan.

Orlova, S., Harper, J. T., \& Sun, L. (2020). Determinants of capital structure complexity. Journal of Economics and Business, 1-19. https://doi.org/10.1016/j.jeconbus.2020.105905

Putri, S. N. A., \& Puryandani, S. (2021). The Influence of Cash Flow , Leverage and Profitability on Investment Decisions in Financial Distress Companies ( All Companies Listed on Indonesia Stock Exchange of 2017-2019 ). Advances in Economics, Business and Management Research, Volume, 169(December 2019), 447-452.

Ramli, N. A., Latan, H., \& Solovida, G. T. (2019). Determinants of capital structure and firm financial performance - A PLS-SEM approach: Evidence from Malaysia and Indonesia. Quarterly Review of Economics and Finance, 71, 148-160. https://doi.org/10.1016/j.qref.2018.07.001

Rosita, M., \& Gantino, R. (2017). Pengaruh Utang Terhadap Profitabilitas Pada Perusahaan Food \& Beverage Yang Terdaftar Di Bursa Efek Indonesia Periode 2011-2015 dan Earning Per Share Perusahaan Food. Jurnal Riset Akuntansi Dan Keuangan, 5(1), 12431260. ISSN: 2541-061X (online). ISSN:2338-150.

Ross, S. A., Westerfield, R., Jaffe, J., \& Jordan, B. (2017). Essentials of Corporate Finance (9e) (Ninth Edit). McGraw-Hill Education. file:///Files/22/2202987B-E44F-49F8-96160F638F13C4E0.pdf

Safitri, O. N., Handayani, S. R., \& Nuzula, N. F. (2014). The Influence of Capital Structure and Proftability on Firm Value ( A Study in Retail Companies Listed in Indonesia Stock Exchange 2010-2013 period ). Jurnal Administrasi Bisnis, 13(2), 1-19.

Saif-Alyousfi, A. Y. H., Md-Rus, R., Taufil-Mohd, K. N., Mohd Taib, H., \& Shahar, H. K. (2020). Determinants of capital structure: evidence from Malaysian firms. Asia-Pacific Journal of Business Administration, 1, 1-44. https://doi.org/10.1108/apjba-09-2019-0202

Soewignyo, T. I. (2020). Analysis of the Effect of Profitability, Solvability , and Dividend Policy on Banking Firm Value. Human Behavior, Development and Society, 21(1), 28-37.

Sukasa, Lolita; Suhadak; Hidayat, R. R. (2017). The Influence Of Corporate Governance And Capital Structure ( Studies on Companies that were Rated in CGPI Listed on The Indonesia Stock Exchange For 2011-2015 ). Jurnal Administrasi Bisnis (JAB), 42(1), 6674.

Tauke, P. Y., Murni, S., \& Tulung, J. E. (2017). Pengaruh Kinerja Keuangan Terhadap Nilai Perusahaan Real Estate and Property Yang Terdaftar Di Bursa Efek Indonesia Tahun 2012-2015. Jurnal EMBA, 5(2), 919-927.

Vo, X. V. (2017). Determinants of capital structure in emerging markets: Evidence from Vietnam. Research in International Business and Finance, 40, 105-113. https://doi.org/10.1016/j.ribaf.2016.12.001

Wassie, F. A. (2020). Impacts of Capital Structure: Profitability of Construction Companies in Ethiopia. Journal of Financial Management of Property and Construction, 5(3), 371-586. https://doi.org/10.1108/JFMPC-08-2019-0072

Zhang, D., \& Liu, D. (2017). Determinants of the capital structure of Chinese non-listed enterprises: Is TFP efficient? Economic Systems, 41(2), 179-202. https://doi.org/10.1016/j.ecosys.2016.12.003 
Zulvia, Y. (2019). Pengaruh Debt To Equity Ratio (Der) Dan Debt To Total Asset Ratio (Dar) Terhadap Profitability Pada Perusahaan Manufaktur Yang Terdaftar Di Bursa Efek Indonesia (Bei) Periode 2014-2017. Economac, 3(2), e-ISSN: 2549-9087 p-ISSN: 14123290. http://economac.ppj.unp.ac.id/index.php/economac/article/view/93/52 